\title{
Surgical management of benign peripheral nerve tumors
}

\author{
Julius July ${ }^{1}$, Abhijit Guha ${ }^{2}$
}

\begin{abstract}
Abstrak
Tumor saraf perifer merupakan lesi yang jarang, dan bisa timbul pada berbagai tempat di tubuh. Sebagai akibatnya, lesi tersebut dapat memiliki differensial diagnosis yang luas. Tumor saraf perifer sering timbul sebagai massa yang tidak spesifik dan diagnosa ditegakkan intraoperatif. Penderita dengan tumor saraf perifer bisa berobat ke berbagai dokter bedah. Pengenalan dini sifat-sifat dan perjalanan lesi tersebut serta tindakan pembedahan yang tepat oleh dokter bedah yang ahli dalam bidang saraf perifer, merupakan hal yang penting untuk meminimalkan defisit neurologik pasca bedah. Tujuan tulisan ini adalah memberikan skema penatalaksanaan secara umum untuk tumor saraf perifer benigna yang paling sering ditemui. (Med J Indones 2008; 17: 163-8)
\end{abstract}

\begin{abstract}
Peripheral nerve tumors are rare lesions that can arise anywhere in the body and hence have a myriad of wide differential diagnosis. They commonly present as a non-specific mass which is diagnosed as a peripheral nerve tumor at surgery. While these tumors may initially be referred to a wide variety of surgeons, early recognition of the nature of the lesion and appropriate surgical treatment by an expert peripheral nerve surgeon is essential in order to minimize post-operative neurological deficits. The objective of this article is to provide a general management scheme for the most common setting of benign peripheral nerve tumors. (Med J Indones 2008; 17: 163-8)
\end{abstract}

Keywords: Operative technique. Schwannoma. neurofibroma

Peripheral nerve tumors (PNTs) are rare soft tissue lesions that can arise anywhere in the body and hence have a myriad of differential diagnosis. They commonly present as a non-specific mass lesion which is diagnosed as a peripheral nerve tumor at surgery. While these tumors are often initially referred to other surgical disciplines and subsequently sent to a peripheral nerve unit after biopsy, early recognition of the nature of the lesion and appropriate surgical treatment, by a surgeon with expertise in peripheral nerve surgery, is essential in order to minimize postoperative neurological deficits.

\footnotetext{
${ }^{1}$ Division of Neurosurgery, Toronto Western Hospital, University Health Network, Univ. of Toronto, Staff Neurosurgeon, Department of Neurosurgery, Siloam Lippo Karawaci Hospital, Medical School of Pelita Harapan University, Tangerang, Indonesia

${ }^{2}$ Department of Surgery, Toronto Western Hospital, and Brain Tumor Centre, Hospital for Sick Children, Universiy of Toronto, Ontario, Canada
}

In this review we highlight the general management scheme including classification, history and physical examination, other examinations to support a diagnosis, operative technique and post operative management.

\section{Classification}

All cellular elements that comprise a peripheral nerve can theoretically give rise to PNTs. The overall rarity of PNTs compared to other soft tissue tumors plus uncertainty regarding the cell of origin, the classification of these tumors, of which several exists, is somewhat confusing. The commonly used term "nerve sheath tumors" is ambiguous, since the "nerve sheath" is comprised of several cell types including perineural cells, Schwann cell and fibroblasts.

A simplified classification scheme is presented in Table 1. The tumors are classified as either benign or malignant, and sub-classified according to their origin from either neural or non-neural elements. This classification scheme, although not comprehensive due to wide range of very rare pathological sub-types, serves well in categorizing PNTs. 
Table 1. Classification of peripheral nerve tumors

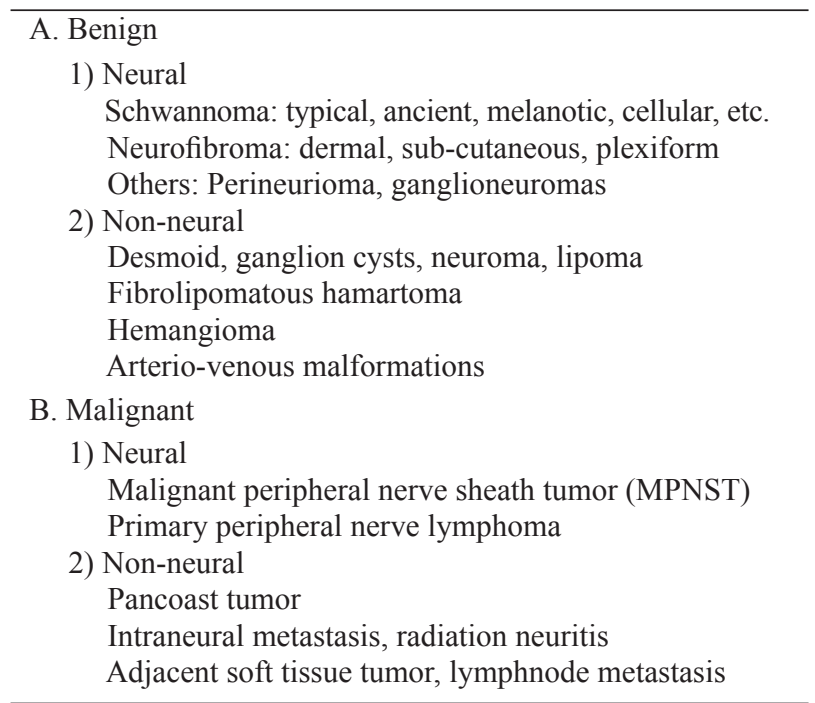

\section{History and Physical Examination}

When a peripheral mass is associated with sensory and/ or motor symptoms supplied by a known peripheral nerve, the suspicion of a peripheral nerve tumor is readily apparent. Then a focused history of the patient with a PNT should be directed toward the onset, duration, and growth alterations of the mass. A family history of neurofibromatosis-1 (NF-1) or neurofibromatosis - 2 (NF-2) or other predisposition syndromes is of special importance, since the majority of PNTs are linked with these syndromes.

The presence or absence of symptoms and signs such as pain, numbness, weakness, changes in the overlying skin temperature and color, fluctuance, along with the patients general health inquiry including immune status, pre-existing malignancy are of importance in the differential diagnosis. However, many peripheral nerve tumors present without any neurological symptoms due to their slow growth rate or origin (when they developed from a superficial small sensory branch).

Several features of the examination that suggest a peripheral nerve origin: 1- PNTs are mobile perpendicular to but not along the longitudinal axis of a known peripheral nerve. 2- Palpation or percussion (Tinel's sign) of a PNT may elicit sensory stimuli radiating along the distribution of the nerve of origin. 3- A mass in a patient with a genetic predisposition such as neurofibromatosis most likely represents a peripheral nerve tumor.
Further, systemic examination of the patient looking for the clinical features of NF-1, NF-2, and Schwannomatosis should be directed (Table 2).

Table 2. NIH diagnostic criteria for neurofibromatosis type 1 and type 2 and Schwannomatosis

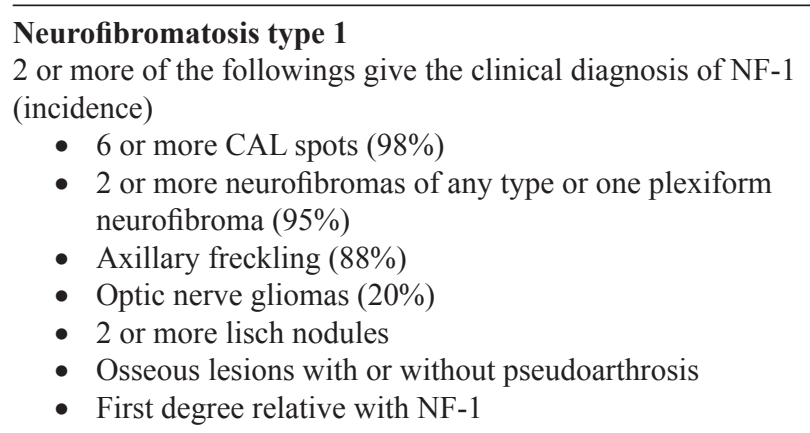

\section{Neurofibromatosis type 2}

Definitive criteria:

- Bilateral vestibular schwannomas (BANF) or

- A family history of neurofibromatosis type 2 in a first degree relative and :

1: unilateral vestibular Schwannoma diagnosed at an age less than 30 years or

2: two or more of the followings meningioma, glioma, Schwannoma, juvenile posterior subcapsular lenticular opacities/juvenile cortical cataract.

Presumptive criteria:

- Unilateral vestibular Schwannoma at age less than 30 years and one of the followings: meningioma, glioma, Schwannoma, juvenile posterior subcapsular lenticular opacities/juvenile cortical cataract, or

- Multiple meningiomas and unilateral vestibular Schwannoma at age less than 30 years, or

- One of the followings: glioma, Schwannoma, juvenile posterior subcapsular lenticular opacities/juvenile cortical cataract.

\section{Schwannomatosis}

Definitive criteria

- Two or more pathologically proven Schwannomas and

- Lack of radiographic evidences of vestibular nerve tumors at an age of over 18 years

Presumptive criteria:

- Two or more pathologically proven Schwannomas, without symptoms of $8^{\text {th }}$-nerve dysfunction, at age of over 30 years or

- Two or more pathologically proven Schwannomas in an anatomically limited distribution (single limb or segment of the spine), without symptoms of $8^{\text {th }}$-nerve dysfunction, at any age

\section{Examinations to support a diagnosis}

Nerve conduction and electromyography (EMG) evaluation are generally not performed in the management of peripheral nerve tumors as they are 
not diagnostic nor do they help in the management decision. However, intra-operative electrophysiology is crucial.

Plain X-ray and computed tomography (CT) scans are occasionally helpful, especially to demonstrate remodeling of adjacent bony structures such as the neural foramina or spinal canal. Angiography or magnetic resonance (MR) angiography is rarely required, and restricted to large PNTs at the base of the neck, chest or retroperitoneum, in close proximity to a blood vessel and/or when vascular invasion may be present. Magnetic resonance imaging (MRI) are the most useful and sensitive technique, that often but not always reveals the nerve of origin (Fig 1). It is especially useful in determining the relationship of the mass to adjacent anatomical structures of relevance.

Although CT scan or MRI cannot distinguish between the various subtypes of PNTs and determine whether a lesion is benign or malignant,,${ }^{1-4}$ MR imaging may be highly suggestive but not diagnostic of the sub-type of PNT. Elements of history and physical examination are often superior in predicting whether the lesion is benign vs. malignant and more likely to predict the subtype of PNT.
A well defined tumor, displaying low T1, high T2 signal with homogeneous contrast enhancement, is highly suggestive of a schwannoma. Occasionally, MR imaging demonstrates the nerves of origin, and displaced passer-by fascicles around the capsule is consistent with the typical extra-fascicular growth of a Schwannoma. In contrast, neurofibromas are more fusiform (spindle shaped) or multi-nodal, suggestive of their typical intra-fascicular growth.

It is important to note that a PNT in the context of an NF-1 patient will most certainly be a neurofibroma vs. an NF-2 patient who likely harbors a Schwannoma.

Lipomas and ganglion cysts, which arise mainly from outside the nerve sheath, have characteristic clues on MR imaging. Lipomas have the characteristics of bright $\mathrm{T} 1$ and $\mathrm{T} 2$ signals, while ganglion cysts show bright $\mathrm{T} 2$ signal with an origin that can be traced to a joint capsule in the proximity of a nerve.

Newer techniques using magnetic resonance neurography (MRN) have the potential to offer better visualization and separation between the nerve lesions and surrounding soft tissue $e^{5,6}$

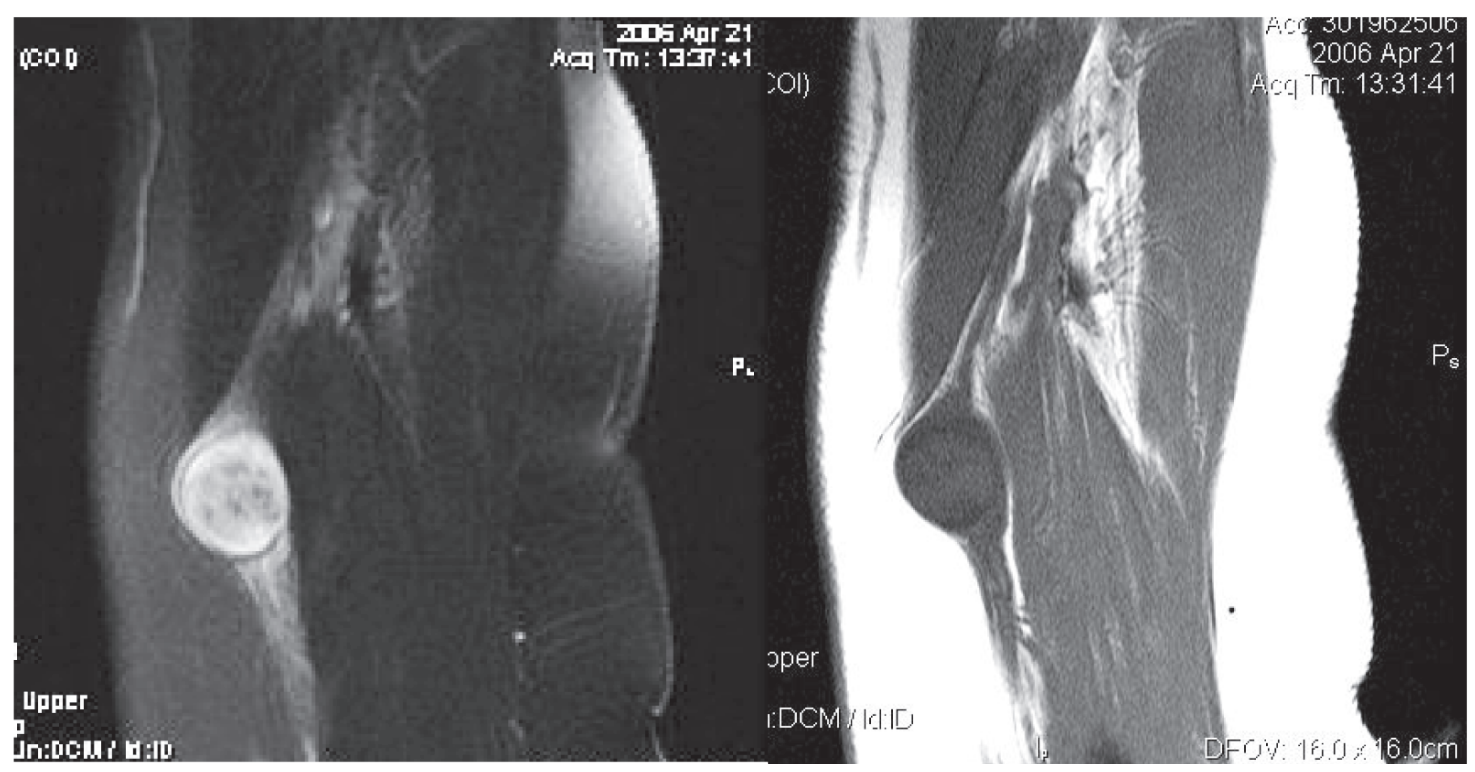

Figure 1. T1 with contrast (left) and T2 (right) MRI of left arm, showing left median nerve Schwannoma also showing the course of the median nerve. 
Magnetic resonance imaging of PNTs may demonstrate heterogeneous changes, indicating intra-tumor hemorrhage, necrosis or cystic degeneration. However, relationship to malignancy is poor. In fact, there are no definitive radiological features of a malignant peripheral nerve sheath tumors (MPNST), a diagnosis mainly suspected on rapid clinical and radiological growth, progressive neurological deterioration and most importantly pain. The use of [F-18]-fluoro-2- deoxy-D-Glucose $\left({ }^{18} \mathrm{FDG}\right)$ PET scanning, a technique for dynamic imaging of glucose metabolism, ${ }^{7-10}$ is of potential promise in distinguishing MPNST from benign PNTs. Still, one should be aware of the occasional false-negative results with this modality. ${ }^{11}$ Initial studies have shown that ${ }^{18}$ FDG-PET can be used to identify soft tissue sarcomas, metastases, histological grade and potentially malignant transformation of a benign plexiform neurofibroma to a MPNST. In those instances where malignant transformation is probable but not yet confirmed, biopsy of the lesion before surgery is essential. The TruCut biopsy can be performed in the outpatient clinic under local anesthesia, though due to pathological heterogeneity of MPNSTs, requirement of an adequate and good quality tissue for diagnosis, with the potential of severe neuropathic pain induction, such as an open four quadrants biopsy is needed.

\section{Operative Technique}

There are several operative principles that are applicable for all peripheral nerve tumors, such as:

1) Anesthesia should be performed without neuromuscular paralysis to allow intra-operative nerve stimulation.

2) The limb should be positioned and draped to allow anatomical accessibility and evaluation of the distal muscles that are supplied by the nerve of origin.

3) The incision over the tumor should extend proximally and distally to allow adequate exposure of the nerve of origin at either pole of the tumor, coursing in a curvilinear fashion over flexor/ extensor creases. If the tumor is adjacent to a known entrapment point such as the carpal tunnel or fibular head of the knee, the incision should allow prophylactic release of the entrapment point in conjunction with tumor removal.
4) Magnification, intraoperative electrophysiological monitoring including nerve action potentials (NAP), and microneurosurgical instruments should be ensured. Ultrasonic aspiration is sometimes required to internally debulk large PNTs, which allows the tumor capsule to be collapsed and facilitating subsequent dissection of the passerby fascicles from the tumor capsule.

5) The first step of dissection involves isolating of the proximal and distal segments of the nerve of origin from adjacent vascular and soft tissue structures and encircling them in vessel loops (Fig. 2A,B, and C).

6) Gross observation of the tumor and the position of the displaced fascicles will often reveal the underlying pathology and vital to avoid injuring the nerve during tumor removal. ${ }^{12-14}$ In schwannomas, passerby fascicles will be found displaced relative to the tumor capsule, though they may be quite attenuated. The routes of these fascicles should be noted microscopically and evaluated with electrical stimulation noting distal muscle activity (Fig. 2B). Neurofibromas in contrast typically do not reveal the discrete passerby fascicles, as nerve fascicles are found within the tumor. However, several major fascicles may be displaced around the bulk of the tumor and their position in the tumor capsule should be noted. (Fig 2D and E).

7) A small biopsy of the tumor from an electrically silent region is sent for pathological verification. The pathology in conjunction with the gross and microscopic observation will determine the feasibility of total removal (as in Schwannomas) vs. limited resection (as in neurofibromas, and desmoids). If the quick section pathology suggests a neurogenic sarcoma, then we recommend closure of the wound and to follow the management of malignant peripheral nerve sheath tumor. Detail discussion on this topic is beyond the scope of this article, the reader is referred to several review articles. ${ }^{15,16}$

Using the principles outlined above, a single nerve fascicle which gives rise to the Schwannoma can usually be isolated and electrophysiologically confirmed to be non-conducting, and then total removal of the tumor can be undertaken (Fig. 2C). 


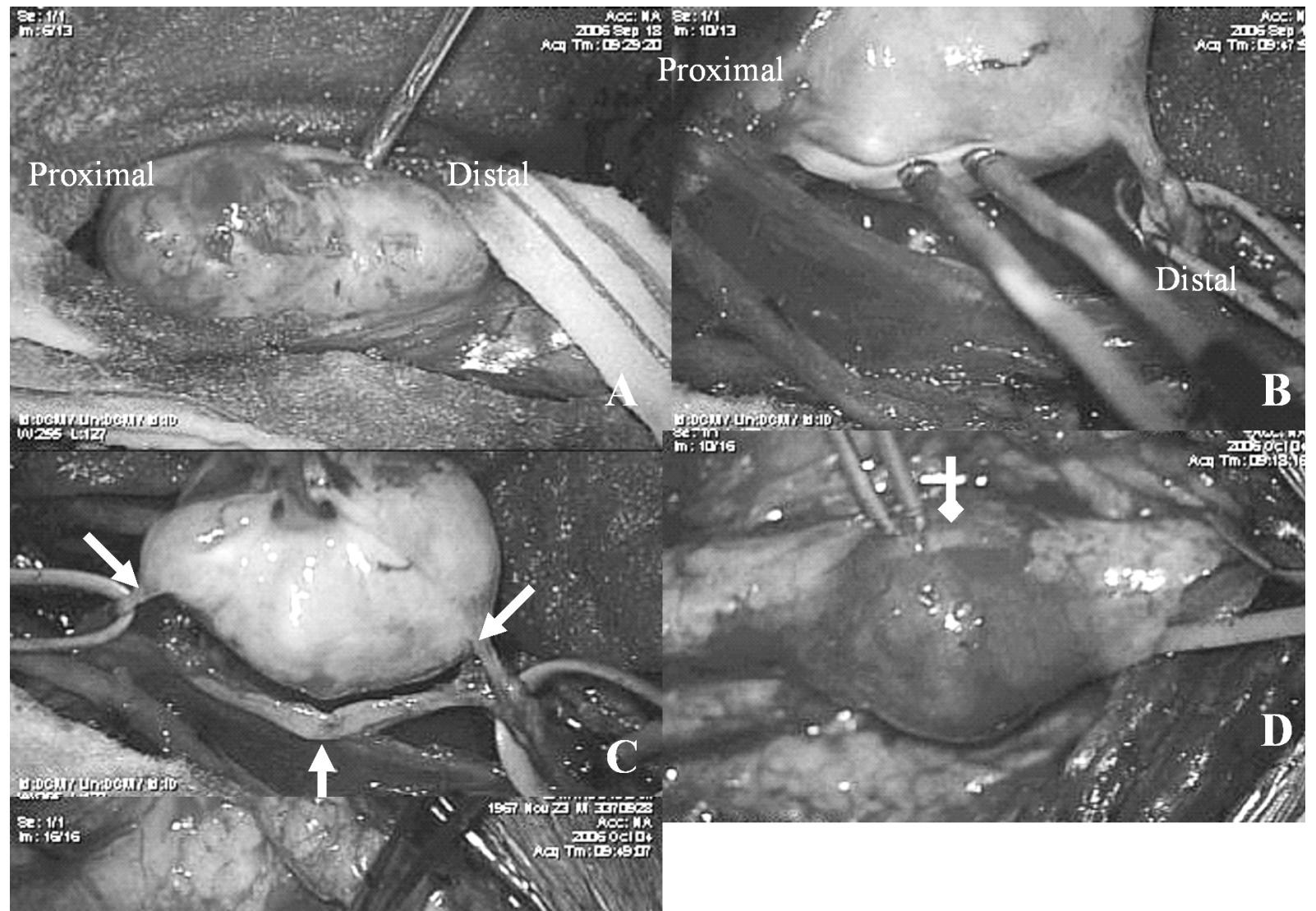

Figure 2. Intraoperative pictures of left posterior tibial nerve Schwannoma, A: exposing proximal and distal pole, B: stimulating to identify the nerve, distal nerve was looped, $C$ : nerve fascicle of origin (yellow arrow), passerby fascicle (green arrow), D: another case with right posterior tibial nerve Schwannoma with fascicles surrounding the tumor (diamond arrow), E: after removal (oval arrow).

\section{Post Operative Management}

After surgery, patient will be put on regular dressing and should rest on that particular limb for one or two weeks, then start with gradual exercise. Special attention should be directed to avoid lifting heavy things or weight bearing exercise for at least 4-6 weeks.

\section{REFERENCES}

1. Lin J, Martel W. Cross-Sectional Imaging of Peripheral Nerve Sheath Tumors; characteistic signs on CT, MR Imaging, and Sonography. AJR. 2001;176:75-82.

2. Murphey MD, Smith WS, Smith SE, Kransdorf MJ, Temple HT. Imaging of musculoskeletal neurogenic tumors: radiologic-pathologic correlation. Radiographics. 1999; 19:1253-80.

3. Grant GA, Britz GW, Goodkin R, Jarvik JG, Maravilla $\mathrm{K}$, Kliot M. The utility of magnetic resonance imaging in evaluating peripheral nerve disorders. Muscle Nerve. 2002; 25:314-31.

4. Murphey MD, Smith WS, Smith SE, Kransdorf MJ, Temple HT. From the archives of AFIP. Imaging of musculoskeletal neurogenic tumors: radiologic-pathologic correlation. Radiographics. 1999;19:1253-80.

5. Kuntz C, Blake L, Britz G, Filler A, Hayes CE, Goodkin $\mathrm{R}$, et al. Magnetic resonance neurography of peripheral nerve lesions in the lower extremity. Neurosurgery. 1999; 39(4):750-6. 
6. Filler AG, Haynes J, Jordan SE, Prager J, Villablanca JP, Farahani K, et al. Sciatica of nondisc origin and piriformis syndrome: diagnosis by magnetic resonance neurography and interventional magnetic resonance imaging with outcome study of resulting treatment. J Neurosurg Spine. 2005;2(2):99-115.

7. Gupta G, Maniker A. Malignant Peripheral Nerve Sheath Tumors. Neurosurg Focus. 2007;22(6):E12.

8. Singh T, Kliot M. Imaging of Peripheral Nerve Tumors. Neurosurg Focus. 2007;22(6):E6.

9. Adler LP, Blair HF, Makley JT, Williams RP, Joyce MJ, Leisure $\mathrm{G}$ et al. Noninvasive grading of musculoskeletal tumors using PET. J Nucl Med. 1991;32:1508-12.

10. Lucas JD, O’Doherty MJ, Wong JCH, Bingham JB, McKee $\mathrm{PH}$, Fletcher CDM, et al. Evaluation of fluorodeoxyglucose positron emission tomography in the management of soft tissue sarcomas. J Bone Joint Surg. 1998;80:441-7.
11. Hsu CH, Lee CM, Wang FC, Fang CL. Neurofibroma with increased uptake of (F-18)-fluoro-2-deoxy-D-Glucose interpreted as a metastatic lesion. Ann Nucl Med. 2003; 17:609-11.

12. Ball JR, Biggs MT. Operative steps in management of benign nerve sheath tumors. Neurosurg Focus. 2007; 22(6):E7.

13. Kline DG, Hudson AR, Kim DH. Atlas of Peripheral Nerve Surgery. $2^{\text {nd }}$ ed. Philadelphia: WB Saunders; 2001.

14. Tiel R, Kline D. Peripheral nerve tumors: surgical principles, approaches, and techniques. Neurosurg Clin N Am. 2004; 15:167-75.

15. Angelov L, Davis A, O'Sullivian B, Bell R, Guha A. Neurogenic Sarcomas: experience at the University of Toronto. Neurosurgery. 1998;43(1):56-64.

16. Perrin R, Guha A. Management of Malignant Peripheral Nerve Tumors. Neurosurg Clin N Am. 2004;15(2):203-16. 